An Honorary Foreign Council, including the names of most of the best known foreign hygienists, has been appointed, and also an Honorary Council of the British Empire, with representatives from India and the colonies.

A Bacteriological Museum and Laboratory will be a special feature in connection with the work of the second Section ; and an exhibition of drawings of sanitary construction, in connection with the work of the sixth Section, will be arranged in the Library of the University of London, under the direction of $\mathrm{Mr}$. Thomas W. Cutler.

As is usual in gatherings of this kind, a considerable number of entertainments, excursions, \&c., have been arranged for, including an entertainment at the Guildhall, conversaziones at the Royal Colleges of Physicians and of Surgeons, and a dinner and fête at the Crystal Palace.

A Ladies' Committee, under the presidency of Mrs. Priestley, has also been formed for the purpose of holding receptions and of organizing visits to various places of interest for the benefit of the ladies who may take this opportunity of visiting London.

A daily programme will be issued, giving the titles of the papers to be read, and the list of excursions, entertainments, \&c., for each day; and besides this, Public Flealth, the journal of the Society of Medical Officers of Health (under the editorship of Mr. A. Wynter Blyth) will issue a special daily number during the Congress, giving abstracts of the more important papers in each Section.

A volume of abstracts of papers will also be issued, and a special hand-book for London is being prepared by Messrs. Cassell and Co. in French and English; this wil contain several maps and plans, and will be mainly devoted to those matters which have a special interest for members of a Congress of Hygiene and Demography.

After the Congress a volume of Transactions will be published, to a copy of which each member will be entitled. The subscription is $\mathcal{E} \mathbf{I}$, and the offices are at 20 Hanover Square.

\section{THE ORIGIN OF CERTAIN MARBLES.}

$A$ MONGST the interesting collection of rocks brought home by Prof. Haddon from 'Torres Straits are some fragments of wind-blown coral-sand rock from Thursday Island. They have a deceptively oolitic appearance, and the majority of the grains being of a red colour give a prevailing warm tint to the stone, and thus render more conspicuous by contrast a number of dark green, worn, and rounded crystals of augite, which are scattered irregularly through it. The appearance of this handsome rock is sufficiently striking, but it gains greatly in interes from its suggestive resemblance to the famous Tiree marble, wherein likewise green grains of pyroxene are set in a fleshcoloured matrix of altered limestone. The comparison is confirmed and enhanced by an examination of thin slices; in the recent limestone the calcareous grains are found, as so commonly happens with these coral-sand rocks, to consist of rounded fragments of calcareous Algæ, and worn tests of various species of Foraminifera; mingled with these are more or less rounded crystals, not only of green augite, but also of olivine, felspar, and a finely crystalline glassy basalt; in the Tiree marble the green grains of pyroxene (salite) show beautifully rounded outlines, and are sharply separated from the surrounding matrix, into which they show no tendency to pass ; crystals of felspar are also pre sent-some fairly fresh, others, and these are the majority, corroded and almost entirely replaced by calcite, only the thin outer skin of the felspar preserving a fresh appearance ; in some few cases, fragments of felspar partially penetrated by salite are met with. The calcareous matrix is finely granular, possibly dolomitic, but blotched and spotted by badly defined larger crystalline individuals of calcite, the outlines of which are sometimes obscurely rounded, so that although no trace of organic structure can now be recognized, yet on the whole the appearances are such as might be expected to be presented by a coral-sand rock, which had suffered metamorphic changes. Macculloch, in his detailed account of this rock, refers to its occurrence as an irregular mass, completely surrounded by gneiss; another white limestone occurs in the island, similariy disposed.

It is interesting to speculate on the final result of pressure metamorphism, acting on volcanic islands surrounded by their reefs. Thus, were the ancient granite masses of Queensland and New Guinea to approach one another, moving towards the line

I A Suggestion: by Profs. Sollas and Cole.

NO. I I 35 , vor. 44$]$ of weakness which now forms Torres Straits, we may conceive that basic schists in great variety would arise from the rolling out of the cores and superficial deposits of the intervening volcanoes; while the associated coral reefs would be converted into irregular masses of structureless limestone, and becoming involved in the surrounding schists would be irregularly dispersed through them, so as to occur in unexpected and anomalous positions.

In conclusion we would call attention to an important paper, read in 1876 , by Mr. W. I. Green, Minister of Foreign Affair to the King of the Sandwich Islands (footnote, Journ. Roy. Geol. Soc. Ireland, vol. iv. p. 140, I877). Inter alia, he says :-

"The Hawaiian Islands are more or less surrounded by coral reefs, the island of Hawaii less so than the others, for one reason, because the lava has kept pouring into the sea along most parts of the coast during past centuries, and has not given the coral an opportunity to form to so large an extent as in the other islands. Now it is a fact that wherever the lava runs into the sea, or wherever the waves have an opportunity of breaking against [it], a large quantity of olivine sand is formed. The felspar, the other material of which this lava is mainly composed, gets ground up to powder and disappears-indeed, it is almost always in the minutest grains to begin with; whilst the olivine, a much heavier mineral, and in grains from the size of a bean to a pea downwards, forms the main component of the sand of the seashore wherever the sea meets the lava, or else the olivine-sand gets more or less mixed up with the coral-sand, where the two classes of rock are in close proximity. A great deal of the olivine-sand is of the finest possible quality ; indeed, it is often so fine that although a much heavier mineral than carbonate of lime, it will often, where both are washed by the waves, settle on the top of the coral-sand, and I have often scraped the almost pure fine olivine-sand from the top of a coral-sand beach. This mixture of the two sands is common over the group, extending 400 miles from Hawaii to Bird Island." Again, " there is every grade of mixture from all coral to all olivine. Very often the olivine-sand rock will be found to run in streaks amongst the coral-sand rock, so that in the course of time, when the coral-sand rock comes to be metamorphosed into a limestone or a marble, the olivine-sand rock would probably suffer the change which that mineral is well known to experience-namely, into serpentine."

These views will certainly commend themselves to many of those who have come to regard Eozoon as a mineral structure. With the presumption in its calcareous composition of an organic origin, there has always existed a suspicion that some such explanation as this might eventually be found. It is interesting to note that the streakiness which Mr. Green expressly mentions as characterizing the interlamination of the olivine and coral sand, is so frequently an accompaniment of "Eozoonal" and serpentinous limestone.

\section{IS THE MARINER'S COMPASS A CHINESE INVENTION?}

A WRITER in the Nort/ China Herald of Shanghai devotes a learned article to detailing and discussing the facts regarding the claim of the Chinese to have invented the mariner's compass. They did not learn the properties of the magnetized needle from any other country. They found it out for themselves, though it is impossible to point to the man by name who first observed that a magnetized needle points north and south. $\mathrm{He}$ suggests that it came about in this way. The Chinese have in their country boundless tracts of ironstone, and among these no small portion is magnetic. Every woman needs a needle, and iron early took the place of the old stone needles, and were commonly used before the time of Ch'in Shih-huang-that is, more than twenty-one centuries ago. Whenever a needle happened to be made of magnetic iron, it might reveal its quality by falling into a cup of water, when it happened to be attached to a splinter of wood, for example. It came in some such way to be known commonly that certain needles had this quality. The great producing centre for magnetic iron is T'szchou, in Southern Chihli. This city was very early called the City of Mercy, and the magnetic stone produced there came to be known as the stone of T'szchou, and so t'szshih became the ordinary name for a magnet. Later, the Chinese began to speak of the City as the "City of the Magnet," instead of calling it the "City of 
Mercy." The polarity of the magnetic needle would become known to the Chinese of that city and its neighbourhood first. The first who noticed the polarity would be some intelligent person who communicated the fact as an unaccountable peculiarity in an age when omens and portents were diligently sought for in every natural object and phenomenon.

The earliest author who mentions the "south-pointing needle" lived in the fourth century B.C. There can be no reasonable doubt that the polarity of the needle was known at that time. The discovery of the fact must have preceded the invention of any myth embracing it. As to the discovery, there is no reason to suppose it was in any way foreign, because the Chinese use an enormous number of needles, and have an inexhaustible supply of ironstone. But though the polarity was known, it was not turned to a practical use till the Tsin dynasty, when landscapes began to be studied by the professor of fengshui, or geomancy. There was at that time a general belief in the magical powers of natural objects. This was a Buddhist doctrine, and it took firm hold on the Chinese mind of that age. The Chinese philosophers of those times taught that indications of good and ill luck are to be seen all through Nature. The polarity of the needle would take its place in this category of thought. Though it is not distinctly mentioned by writers of the fourth century, yet to their disciples it became an essential part of the landscape compass which the professors of fengshui all use. Kwo $\mathrm{Pu}$, the founder of this system, died A.D. 324, and it was not till four centuries later that the fengshui compass began to assume its present form. The compass used by the professors of geomancy for marking landscape indications was first made about the eighth century. It was of hard wood about a foot wide, and it had in the centre a small well in which a magnetized needle floated on water. On the compass were inscribed several concentric circles, as on the wooden horizon of our globes. They embrace the twelve double hours, the ten denary symbols, eight diagrams, and other marks. This compass was used in preparing a geomantic report of any spot where a house or tomb was to be constructed, so that the construction might not be upon an unlucky site or planned in an unlucky manner. At the same time there was living a Chinese who had studied Hindoo astronomy, and was the Imperial astronomer, and also a Buddhist priest. He noticed that the needle did not point exactly north, and that there was a variation of $2^{\circ} 95^{\prime}$. This variation went on increasing till a century later - that is, till the ninth century. A professor of geomancy then added a new circle to the compass. On this improved compass the first of the twelve hours begins on the new circle at $7^{1}{ }^{\circ}$ east of north.

The compass, it will be observed, grew out of the old astrological report or nativity paper, calculated from the position of the stars, and prepared in the Han dynasty by astrologers as a regular part of social life, especially when marriages were about to be solemnized. Some of the old astronomical circles are preserved in the new geomantic chart. This was the compass used when Shen-kwa wrote on the south-pointing needle in the eleventh century. This author mentions that any iron needle acquires polarity by rubbing it on a piece of loadstone. $\mathrm{He}$ alludes to the variation as a fact which he himself had observed, and speaks of the south-pointing needle as an implement used by the professors of geomancy. By them it was employed in the form of a float upon water. After this, in I r 22, an ambassador to Corea describes the use of the floating needle on board ship while he made the voyage. This is the first instance, the earliest by more than a century, of the use of the mariner's compass on board ship, found as yet in any book, native or foreign. The existence of the book in which this is recorded settles the question of the first use of the mariner's compass at sea in favour of the Chinese. At that time the needle floated on water supported on a piece of wood, but in the Ming dynasty some Japanese junks engaged in piracy were captured by the Chinese, and the compass in use on board was found to have the needle dry and raised on a pivot, while still pointing southward. The Japanese had learned from the Portuguese navigators to make a compass of this kind, and probably the needles they used were brought from Europe. From this time, the Chinese adopted the principle of a pivot, and made their compasses without a well of water in the middle to float the needle in. Charts were probably used of a very rough kind, but how far is not known. What is known is that the junk-master was aware of the direction in which the needle must point to reach the port to which he was going. In the Sung dynasty, em- bracing part of the tenth, as well as the eleventh, twelfth, and part of the thirteenth centuries, Chinese junks went to Persia and India. The Arabs trading to China directly would learn at that time the use of the compass, and would apply it on board their dhows. From them the Europeans learned this useful invention.

The credit of the discovery, both of the polarity of a mag netized needle and its suitability for use by mariners at sea must therefore, according to this writer, be given to the Chinese. I was China also that has the credit of having first noticed that any iron needle may be polarized by rubbing it with a magnet, In the thirteenth century the Arabs used a floating compass on their dhows. The needle was made to float on the water by attaching it crosswise to a cornstick or splinter of wood. A magnet applied to it drew it into a north and south direction. They would use Western notation to mark the quarters and intermediate points on the horizon. When therefore the mariner's compass was adopted from them, the Chinese 24 points were not communicated. In the European compass the notation of 32 points is Western, and rests on the winds and the sun. In the Chinese primitive mariner's compass the notation is that of the professors of geomancy, and rests on the old astrological division of the horizon into twelve double hours. From the Arab account we learn, what the Chinese accounts do not tell us, that the Chinese floated the needle by inserting it in a splinter of wood.

\section{UNIVERSITY AND EDUCATIONAL INTELLIGENCE.}

Royal College of Science.-The following scholarships, prizes, and Associateships have been awarded for the session 1890-91 :- First year's scholarships to William Allan, Thomas T. Bedford, Edwin Edser, and Herbert A. Clark ; second year's scholarships to John W. Pickles and Sydney Whalley; the Edward Forbes Medal and prize of books for biology to Arthur G. Butler ; the Murchison Medal and prize of books for geology to Charles G. Cullis ; a Tyndall prize of books for physics, Course I., to William Allan; the De la Beche Medal for mining to James G. Lawn; the Bessemer Medal and prize of books for metallurgy to Joseph Jefferson; the Frank Hatton prizes of books for chemistry to Herbert Grime and Lionel M. Jones. Prizes of books have been given by the Department of Science and Art in the following subjects:--Mechanics-Charles $H$. Kilby, Charles P. Butler, Herbert A. Clark. Astronomical Physics-Lawrence Parry and Samuel S. Richardson. Practical Chemistry-William A. C. Rogers. Mining-James G. Lawn. Principles of Agriculture and Agricultural ChemistryHenry Wilkinson. Associateships of the Royal College of Science have been awarded as follows :-Mechanics-Ist class, Harold Busbridge and Ernest W. Rees; 2nd class, Angus Leitch. Physics-Ist class, Sidney Wood ; 2nd class, William Shackleton and Alfied B. Lishman. Chemistry-Ist class, Herbert Grime, Lionel M. Jones, Alfred Greeves, William A. C. Rogers, and Morton Ware ; 2nd class, John G. Saltmarsh. Biology (Zoology)--Ist class, Arthur G. Butler and James Harrison. Geology-Ist class, William J. Smeeth. The following Associateships, Royal School of Mines, have also been awarded :-Metallurgy-Ist class, Joseph Jefferson, Alfred Stansfield, John Eustice, and William F. P. Tindall ; 2nd class, John D. Crabtree, Thomas S. Fraser, Henry T. Bolton, Benjamin Young, Hugh F. Kirkpatrick-Picard, George J. Snelus, James R. Crum, and Stanley H. Ford. Mining-Ist class, James G. Lawn, John Yates, Robert Pill, Theodore G. Chambers, Algernon P. Del Mar, Nono Kitto, and George R. Thompson; and class, Reginald Pawle, Charles C. Scott, Henry Cavendish, Gustave Busch, George H. Gough, and Ben Howe.

\section{SCIENTIFIC SERIAIS.}

THE American Meteorological Fournal for June contains :-An account of the meeting of the New England Meteorological Society on April 18 last. The subject of discussion was weather predicting. The general methods of predicting in the United States and Europe were first described, and afterwards local and long-range predictions were considered. Papers were read by J. Warren Smith, on the Signal Service weather forecasts; W. M. Davis, on European weather predictions; $\times A$. L. Rotch, on

NO. I I 35, VOL. 44] 